TURIZAM

Volume 18 , Issue 1

22-32 (2014)

\title{
The Characteristics of Finding Employment abroad in Case of the Szeged Tourism Human Resources (Szeged, Hungary)
}

\author{
Peter Mihaly* \\ Received: January 2014 | Accepted: February 2014
}

\begin{abstract}
Human work provided for tourists is an indispensible element and, in a sense, the very soul of tourism services, and its quality highly influences what image is formed of the travel. By today, the significance of qualified human resources in tourism has been more and more appreciated in Hungary, as one of the conditions of realising internationally competitive tourism is the presence and development of quality human resources. Language knowledge and professional knowledge can make employees more qualified and more in demand both abroad and in the Hungarian labour market.

Based on international statistics, it can be stated that the main target countries of Hungarian employees are Germany, Great Britain and Austria. The majority of Hungarian employees in these countries find jobs in the catering sector.

The present study was conducted in 2012 with the aim of surveying the target countries of finding employment in case of the Szeged human resources of tourism. 874 people working in the Szeged tourism sector were involved in the survey. The data of the participants were examined according to local touristic structure, age group and highest school qualifications. The survey included those as well who had qualifications in tourism and catering.
\end{abstract}

Key words: tourism, human resources, employment, migration

\section{Introduction}

Tourism is compiled of labour-intensive activities (ICEG EC, 2006). One of its main characteristics is its significant need for human labour, and the services provided are not only personal but can hardly be replaced by technological solutions or only to a limited extent (Dávid, et al., 2007). Due to the interdisciplinary nature of tourism, the studies on human resources in tourism, which establish the foundation of tourism services, are mainly conducted in

* Vocational Training, Further Training and Distance Education Centre, Gyula Juhász Pedagogical Faculty, University of Szeged, Hattyas sor 10. 6725 Szeged, Hungary;

mihalypeter@jgypk.u-szeged.hu 
the fields of sociology, geography and demographic studies. In the past two decades, due to the favourable Hungarian and European Union political influences, there have been more and more opportunities for migration into foreign countries with the aim of finding employment. The tourism and catering sector of the recipient countries offers favourable employment opportunities for foreigners. According to the statistical office of Germany, at the end of the I990s, most of the Hungarian immigrants found jobs in the catering industry (Fóti, Németh, 2OO2). Studies focused on these immigrants from the point of view of their finding employment in the catering industry, their opportunities for employment, their salaries and wages (Janta, et al., 2OII), their gender ratios, their levels of qualifications (Janta, 2OII) and their motivations for working abroad (Ladkin, 2OII). Due to the low wages offered, the countries where these people emigrate from suffer from a shortage of qualified work force (Taylor, et al., 2009). Large-scale investment into tourism makes it possible to employ the locally available work force in the tourism sector, which also improves local employment rates (Kiss, 20I2).

If a heritage location lacks the minimum infra- and suprastructure, then it can only receive guests in eco- and adventure tourism. In order to provide for tourists, qualified work force is indispensible. (Nagy, 20O2). The significant touristic development of Hortobágy National Park (Hungary's first national park, it is inscribed on the World Heritage List) has an impact on the employment of the population in the area (Martonné, Vasvári, 2OI2). The human resources of wine cellars participating in Hungarian wine tourism were investigated based on qualifications and language knowledge (Máté, 2OII). A study on the labour market characteristics of health tourism in Hungary was conducted focusing on the employees of medicinal spas and health and wellness hotels (Ruszinkó, Vízi, 2OIO). The first step for settlements having no touristic attractions in order to become part of tourism in the area is to have qualified human resources (Huber, 1996).

The significance of qualified work force has increased in Hungary since the change of the communist regime (1989). In the local labour market in tourism, demand has increased for those employees who are mobile, speak foreign languages and have international experience. In the present paper, this group of employees, who used to find employment abroad, are focused on from various points of views

\section{Main characteristics of the studied area}

According to the data of the Hungarian Central Statistical Office, Szeged is the third biggest city in Hungary, the centre of the Southern Great Plain region, with I70,052 inhabitants. The city lies at the estuary of the Tisza and the Maros, at the junction of motorways E75 and M43, close to the triple border of Serbia, Romania and Hungary. According to archaeological findings, it has been a populated area since prehistoric times. Following the great flood of the Tisza in I879, the city was rebuilt with a modern structure (having a road system with boulevards and avenues) with buildings designed in Eclectic and Art Nouveau architecture. After World War I, the university of Cluj Napoca (Kolozsvár) was moved to Szeged (I92I), together with the bishopric of the Csanád Diocese (1923) (Mihály, Mihály, 2008). Today, Szeged is home to one of the biggest universities of Hungary with 25,775 students in $2 \mathrm{OIO}$ (www.u-szeged.hu). The tourism of the city is built on the medicinal waters, the sacred monuments, the internationally acclaimed open air theatre festival (Mihály 2006), sports events, scientific conferences and the folklore of the region. An unexploited touristic potential of the 
city is the river Tisza, which functions as a border river from Szeged to Kanjiža (Magyarkanizsa) (Mihály, 2007). Besides its eco- and water-tourism features provided by the river, the city offers recreational and sports opportunities in its environs (e.g. fishing, cycling and horse tourism) (Győri, 2OI3).

\section{Methods and data}

The research objective was to investigate the human resources of the tourism sector in a historical city, which has a wide range of touristic offers and a varied compound of employees, and to map the characteristics of employees working here. I have some experience in researching the tourism of Szeged (Mihály, Mihály, 2008; Mihály, 2005; Mihály, 2006; Mihály, 2007; Mihály, 20I3), and I would like to add a new aspect of observations to the field.

Collecting data in the business sector is impeded by the following phenomena: the "time is money" attitude, rivalry, fear for market positions, professional jealousy and a general lack of trust. The author of the present paper managed to establish a network of connections with the prominent actors of local tourism during his decade long work in the field, which could serve as the basis for conducting such detailed and successful research.

The categorization of the touristic offer and actors (local institutes and businesses) of a settlement or region was provided by Kaspar, Lengyel and Michalkó.

Lengyel divides the local infrastructure that influences tourism into two categories. Tourism infrastructure in the narrower sense includes road, water, electricity, telecommunications and sewage networks. Tourism infrastructure in the broader sense, i.e. facilities of receiving guests, includes accommodation, catering, commerce and other touristic services. Sectors that are directly in the service of tourism are built on this broader interpretation of infrastructure (Lengyel, I992).

Kaspar's notion of touristic infrastructure is somewhat different from Lengyel's definition. Kaspar categorizes touristic vehicles of transport (cogwheel railway, cable railway and ski lifts) and local facilities providing recreational and sports activities as infrastructure. The term touristic suprastructure was introduced into tourism theory by the Swiss researcher in the I990s. By touristic suprastructure, he means the accommodation and catering system (Kaspar, 1992, Kaspar, Fekete, 200I).

Michalkó developed and refined the term. Michalkó's definition of touristic infrastructure is the same as Kaspar's notion, however, he divides suprastructure into primary and secondary suprastructure. Primary suprastructure includes accommodation and catering facilities and their services. Secondary suprastructre contains the units of the service industry: currency exchange locations, souvenir shops, market places, shops, department stores, shopping malls, bazaars, car rentals and business offering personal services (Michalkó, 2007).

In the present survey, those service providers and local tourism businesses were addressed who belong to the primary and secondary suprastructure and connect to tourism in Szeged and offer their services for tourists arriving in the city. (This latter point needs to be underlined because of the businesses belonging to the secondary suprastructure). Furthermore, the survey covered the opinions of employees of the local travel agencies, which undertake the organisation of the travelling of Szeged people and are mostly involved in travelling from 
Szeged, however, from the point of view of Szeged people, they play a significant role in tourism in the city.

To determine that the businesses operating in Szeged offer their services not only for tourist but for local people as well, I relied on information provided by the publications of the touristic office of the Local Municipality of Szeged, Szeged guide books, the list of Szeged travel agencies in the database of the Association of Hungarian Travel Agents and Tour Operators (MUISZ) and the recommendations of the members of the Guide-Inform Hungary Club on Szeged institutes and businesses.

Local institutes and businesses were contacted based on this. The study was conducted in 2OI2, with I66 institutes and businesses altogether. 874 people working in the tourism industry filled in the questionnaire. The present study discusses in detail the issue of finding employment abroad earlier. This set of questions was investigated according to the following aspects:

- analysis of age groups

- according to local touristic infrastructure

- according to qualifications

- the study also included people with qualifications in tourism and/or catering

In analysing the findings, I applied the statistical software IBM SPPS.

\section{Findings}

\section{The characteristics of the employment of the Szeged tourism human resources according to touristic structure}

Figure I shows that one quarter of the employees working for touristic businesses in Szeged belonging to the primary and secondary suprastructures already worked abroad. Employees of event organisation companies with local headquarters also belong to the group of local travel agencies. In this category, $25.8 \%$ of the employees worked abroad earlier. The high figures in this category can be accounted for by the fact that a significant proportion of employees in the primary suprastructure and in travel agencies have tourism and catering qualifications. This means that they were motivated by their knowledge obtained during their studies and their language knowledge to find employment abroad. The institutes and businesses of touristic infrastructure serve as the basis of local tourism, on which various businesses of the primary and secondary suprastructure are built. In spite of this, relatively few people possess qualifications of tourism in this category, as in these institutes (e.g. museums, medicinal baths) professional knowledge and skills are of primary importance and qualifications of tourism and, together with it, foreign language knowledge come only second. This situation can be explained by the fact that the activities of institutes run by the local municipality aim at satisfying local demands. Consequently, it is not surprising that only $\mathrm{I} 3.4 \%$ of their employees worked abroad earlier.

Businesses providing other activities, such as guiding or passenger transport with various vehicles (e.g. boat trips, pleasure flights, taxi planes, transfers, etc.), which are connected with tourism and serving tourists belong to the secondary suprastructure. $28 \%$ of employees working in this category (the highest figure in the survey!) already worked abroad. 


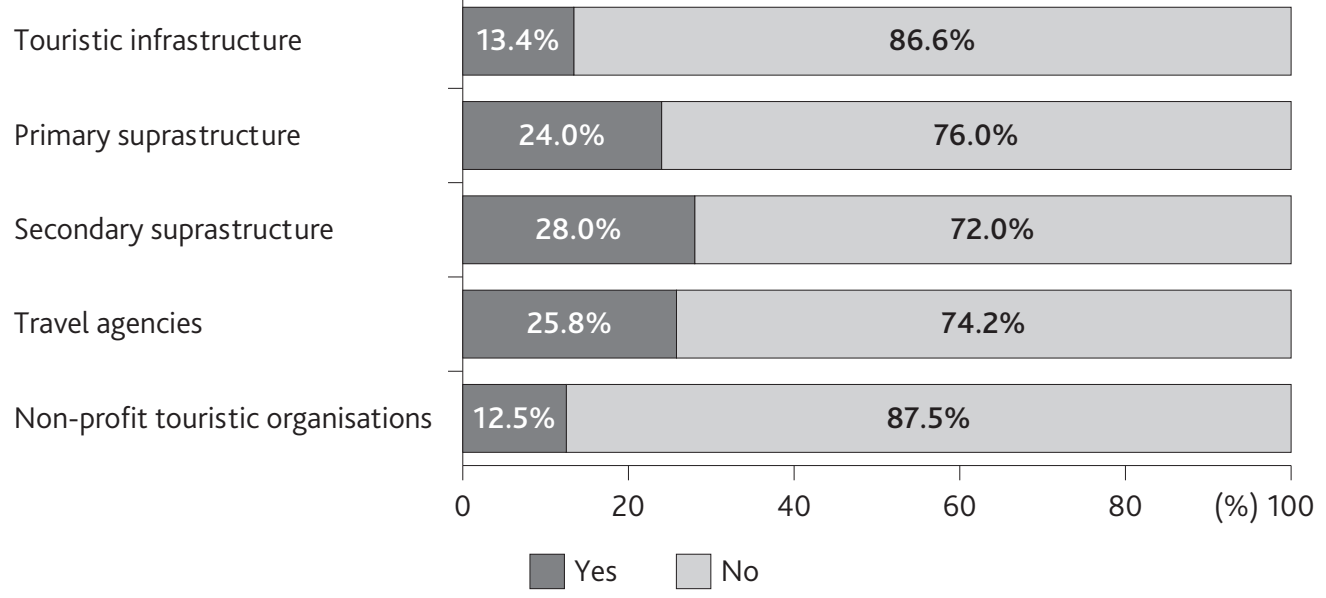

Figure 1. Distribution of employees in Szeged tourism with work experience abroad in 2012 Source: author's own research (2012), table: compiled by the author (2013)

The promotion activities of non-profit organisations working on popularizing the touristic offer and attractions of a settlement are indispensible in a well-functioning touristic system. The task of the Szeged and Environs Touristic Non-Profit Ltd. is to promote the city's touristic offer in Hungary and abroad alike. The ltd. works with a small staff who are qualified in tourism. The municipality-owned company has sound economic foundations and its workers found employment in this non-profit touristic sector right after graduating from university. As a result, only I2.5\% of the employees in this category worked abroad earlier.

Figure 2 depicts the main target countries of migration for finding employment abroad according to touristic structure. The most often given responses are Germany, Great Britain and Austria. However, it is worth mentioning the category of other countries as well. Among employees of businesses and travel agencies belonging to the secondary suprastructure, the category of other countries was rated high (above 50\%). With qualifications and good knowl-

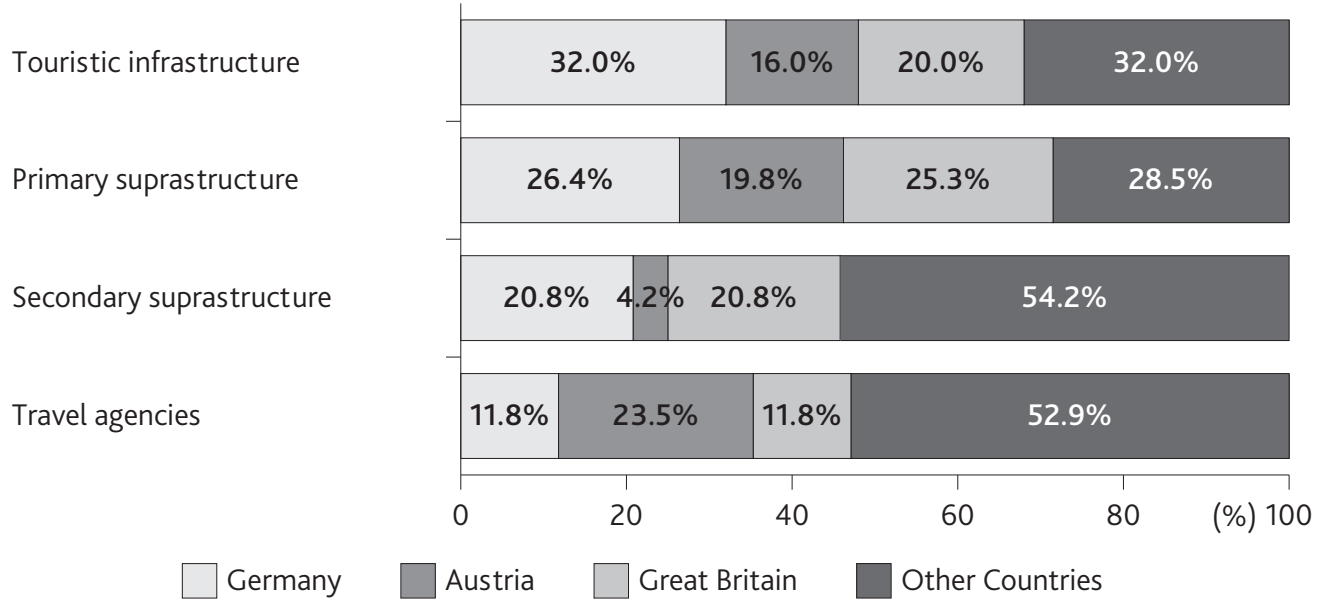

Figure 2. Distribution of the main target countries of migration for finding employment abroad according to employees in tourism in Szeged in 2012

Source: author's own research (2012) Table: compiled by the author (2013) 
edge of a foreign language, they found employment in countries other than the main three target countries. In their case, a subgroup of Mediterranean countries can be detected: Italy, Spain, Greece and France. Another two countries that were popular among them are Switzerland and the United States.

The category of travel agency is represented by over 50\%. This high rate indicates that the phenomenon of over-qualification is typical of these employees. In certain cases, the position (e.g. reservation agents) does not require a college or university degree, however, in order to make a living, they still accept jobs that could be filled with lower qualifications. Foreign language knowledge gained during their years of studies is an advantage when looking for employment. Another characteristic of this group of employees is that they often conducted parallel studies and they supplemented their university education with tertiary level vocational education as well.

\section{The characteristics of finding employment among human resources in tourism in Szeged according to age groups}

Figure 3 clearly shows that $40.2 \%$ of the employees belonging to the $30-39$ age group already worked abroad. In case of the I6-29 and the 4O-49 age groups, $25 \%$ worked abroad. Only $8.3 \%$ of the over 60 respondents worked abroad, which fact can be accounted for by the highly bureaucratic and strictly restricted opportunities for travelling abroad in the socialist era in Hungary; secondly, by the lack of the knowledge of the languages of Western countries; and thirdly, by the fact that in the socialist era the population was surrounded by a strong social network, which provided a sense of security and predictability as for finding employment in Hungary.

The 50-59 age group are represented in a small number in the Szeged tourism sector, however, 30\% of them worked abroad earlier. This age group, small in number, is mainly found in middle or senior management positions in the tourism and catering sector in Szeged. Foreign language knowledge and international work experience play a key role in their employability.

16-29 years old
30-39 years old
40-49 years old
50-59 years old

Above 60

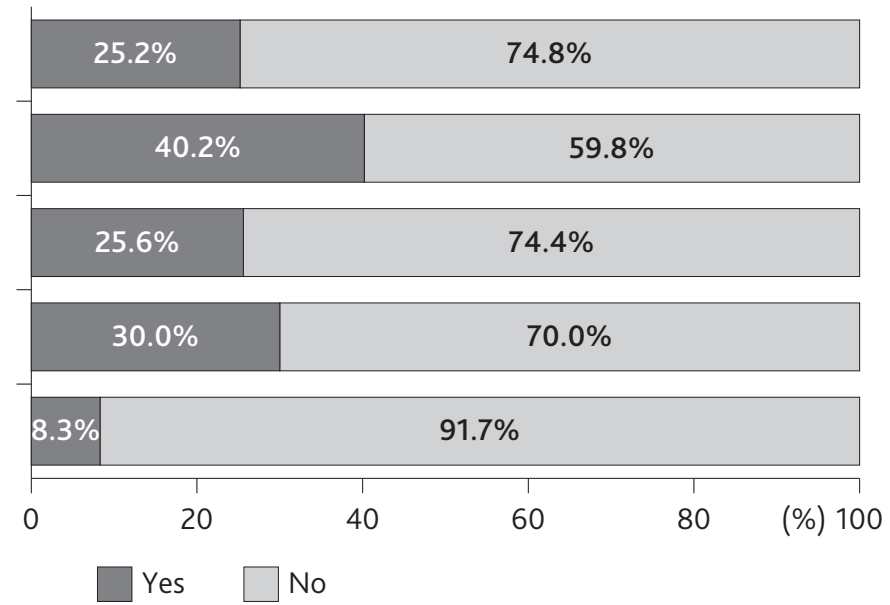

Figure 3. Distribution of finding employment abroad according to age groups in 2012.

Source: author's own research (2012) Table: compiled by the author (2013) 


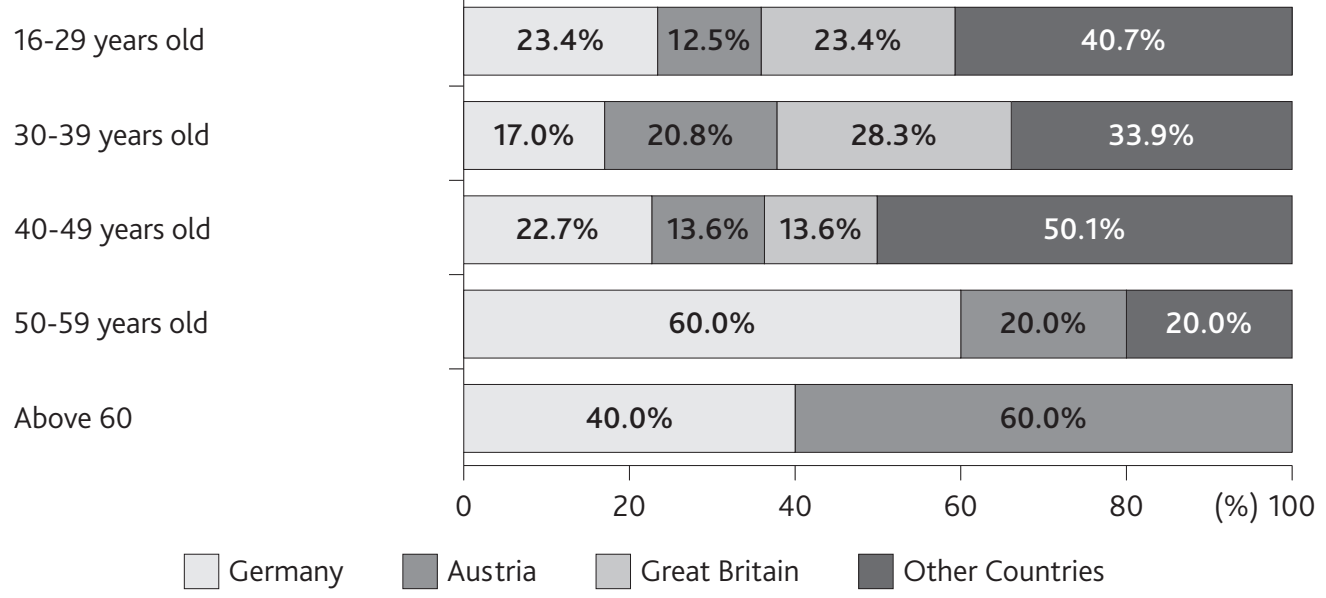

Figure 4. Distribution of target countries of finding employment abroad earlier according to age groups in 2012

Source: author's own research (2012) Table: compiled by the author (2013)

It can be seen in figure 4 that Germany is the most preferred target country among the $50-59$ and the over 60 age groups with $60 \%$ and $40 \%$ respectively. In the age groups below 50, Germany, Great Britain and Austria are represented with different percentages in the different age groups. While in the I6-29 age group Germany and Great Britain appear with the same rates, in the 30-39 age group Great Britain is the number one target country with the purpose for finding employment, with $28.3 \%$. In the above $4 \mathrm{O}$ age groups, German speaking countries seem to be preferred. In the 4O-49 and the 50-59 age groups, Germany is number one. In the 40-49 age group, Austria and Great Britain are represented with the same rate (13.6\%). In the above 50 age groups, Great Britain disappears as a response, while Germany and Austria become preferential. In the above 60 age group, it is the closer German speaking destination that dominates, namely Austria. The high proportion of finding employment in German speaking countries can be accounted for by the fact that in primary and secondary schools German was taught as a school subject; in the socialist educational system, besides Russian, German was the other main foreign language.

\section{Characteristics of the employment of human resources in tourism in Szeged among qualified and non-qualified people}

In this sub-section, people with qualifications in tourism are regarded separately from those who are non-qualified.

Upon comparing figures 5 and 6, it can be stated that - at each level of qualification among those who have qualifications in tourism or catering, the rate of those having worked abroad is IO\% higher than among those who have no such qualifications.

The most striking difference between the data in the two figures is the I8.I\% higher proportion of those having secondary school education. One of the characteristics of those people with qualifications in tourism who have secondary school final exams is that they passed their final exam after having graduated from a vocational school and having studied a few more years to take the exam. It is typical of them that while preparing for the final exam in parallel to their education - they were employed by local or regional touristic businesses. 
Vocational school following

8 years of primary education

Secondary school

Vocational school following secondary school final exam

College - University

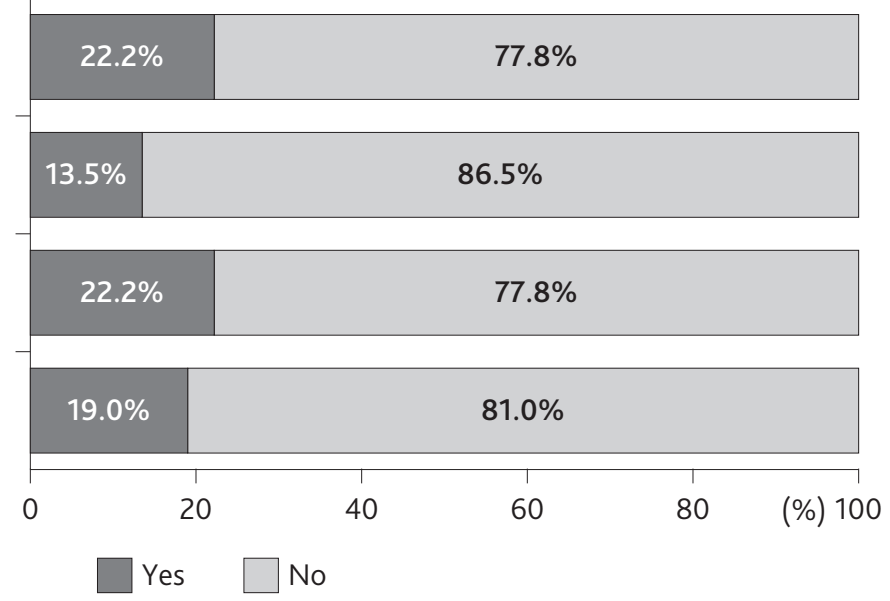

Figure 5. Characteristics of the employment of human resources in tourism in Szeged among those who have no qualifications in tourism/catering in 2012

Source: author's own research (2012) Table: compiled by the author (2013)

Vocational school following

8 years of primary education

Secondary school

Vocational school following secondary school final exam

College - University

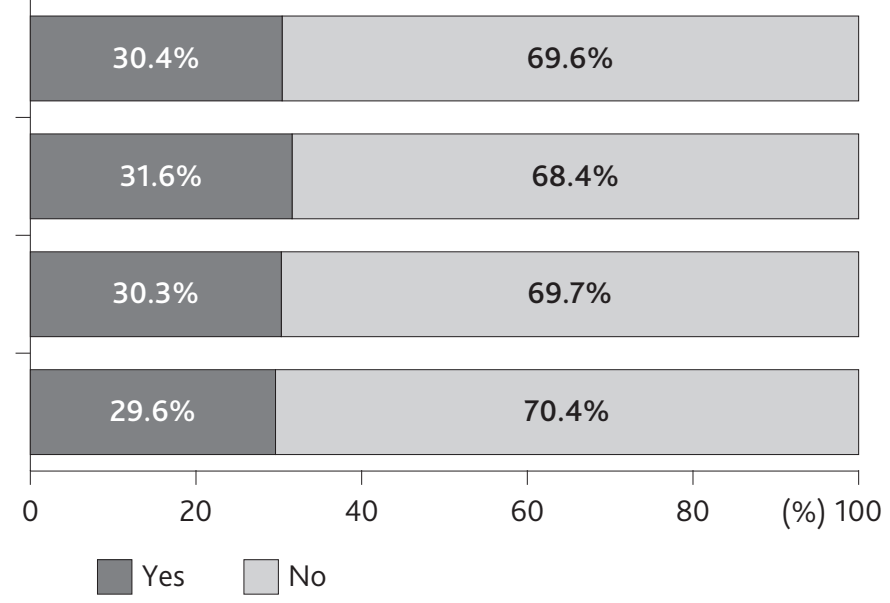

Figure 6. Characteristics of the employment of human resources in tourism in Szeged among those who have qualifications in tourism/catering in 2012

Source: author's own research (2012) Table: compiled by the author (2013)

As we can see, there is no change in the main target countries of migration for finding employment abroad. However, there are two points of interests that are worth noting. One is that among those who have lower levels of schooling, the first two target countries were Germany and Austria. While among those who obtained university or college education, Great Britain was the most popular. Another interesting point can be found when examining the category of other countries: in case of those with secondary school education or university/ college education, the proportion of other countries is higher, namely $45.5 \%$ and $35.8 \%$. It was people with such qualifications who worked in other countries in the highest proportion apart from the 3 main target countries. 


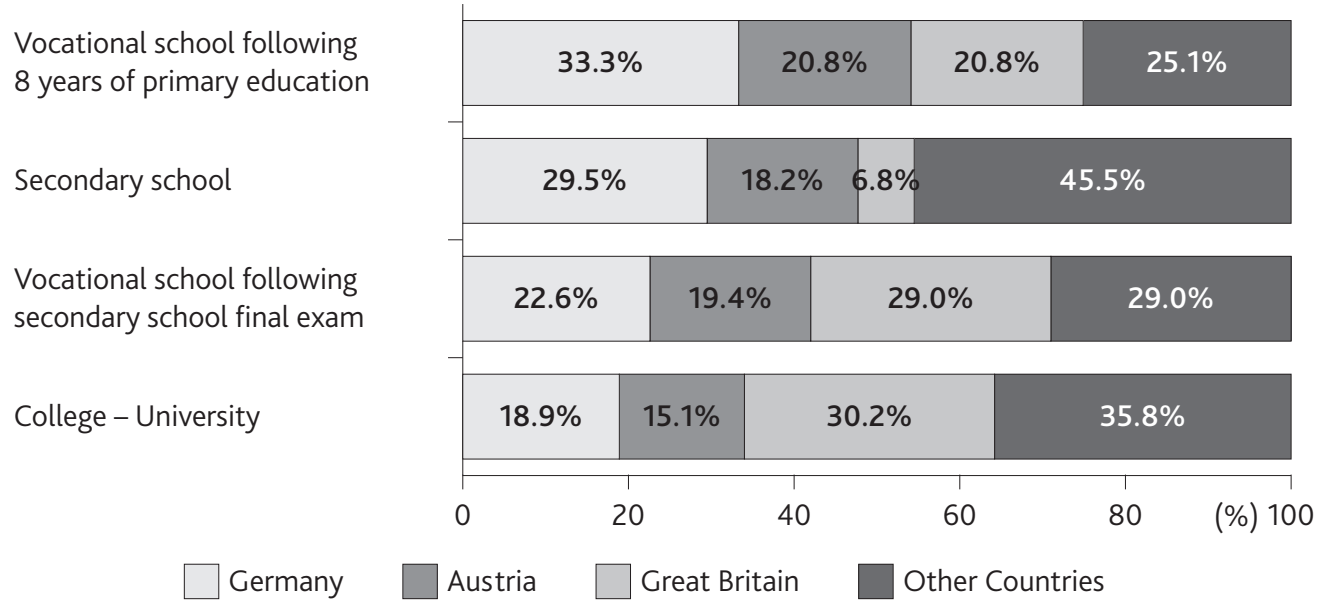

Figure 7. Distribution of target countries of finding employment abroad earlier among people with qualifications in tourism/catering in 2012

Source: author's own research (2012) Table: compiled by the author (2013)

\section{Conclusion}

Based on the above study, the following can be concluded in connection with the characteristics of human resources in Szeged:

Compared to the other touristic structures, among those employed in the local touristic infrastructure, the proportion of those having worked abroad earlier is relatively low. This means that the number of those qualified people who had the opportunity to gain experience about the operations of a touristic institute or touristic business abroad is low. This fact has an impact on the development of the local touristic offer that aims at providing quality and high standards so that the demands of guests arriving from abroad can be fully satisfied.

It is the 30-39 age group of people working in tourism in Szeged that worked abroad in the highest proportion, followed by the under 30 age group. Only a very small proportion of the over 60 age group of people working in tourism worked abroad earlier, which can be accounted for by the fact that the socialist system used to strictly restrict travelling.

It is interesting to note that among the under 40 people it was Great Britain, while in the above 4O, it was German speaking countries that were preferred. It is not surprising as before the change of regime (I989), besides the Russian language - which many people did not find appealing due to emotional reasons - it was German that was taught as a school subject, while after that period, it was English that became dominant right away.

It is remarkable that regardless of the levels of qualifications, one third of people with qualifications in tourism and catering worked abroad.

In the course of the study, a group of countries became prominent in the category of other countries, namely, the group of Mediterranean countries. This indicates that besides the languages of the main target countries (English and German), a second foreign language (Italian, French, Spanish, etc.) is also important to acquire.

It must become an objective that foreign language usage should become routine, which can be fostered by making foreign scholarships and practices widely available. This could 
make the obtained certificates/degrees, and thus the future employees themselves, more marketable in the labour market. This could significantly contribute to the quality enhancement of the Hungarian touristic offer, and such employees would be more in demand in the Hungarian market as well.

The findings of the study also show that in the Szeged touristic sector there are employees who arrived from the neighbouring countries (Romania and Serbia). These employees of Hungarian origin are not regarded as foreign employees in Hungary. The majority of them immigrated into Hungary as a result of the Serbian and Romanian political events in the I99Os. In the course of the 2012 study, they viewed their earlier work experience in their previous countries as working abroad. The majority of them speak the language of the country where they were born like a native language. With such linguistic competencies, only few people appear in the Szeged touristic sector. This is rather unfortunate as Szeged is becoming more and more popular among Serbian and Romanian tourists, which is also indicated by the latest - first IO months of $2 \mathrm{OI} 3$ - statistical data (first IO months of 2OI3, Hungarian Central Statistical Office). "The guest should be addressed in their own language", as the proverb says in the catering industry. Consequently, Serbian and Romanian language courses should be initiated for the actors of the local tourism sector. It should be recommended that at least one employee in each tourism business could acquire this language knowledge.

\section{References}

Dávid, L., Jancsik, A., Rátz, T. (eds.) (2007). Touristic resources. A Touristic comparison of natural and cultural resources. Károly Róbert Főiskola, Gyöngyös. (in Hungarian)

Fóti, K., Németh, M. (20O2). Hungarian citizens' finding employment in the member states of the European Union in the I99Os. Migration and Statistics. I, I34-I54. (in Hungarian)

Győri, F. (2OI3). The sports recreation and sports tourism offer in Szeged and its environs built on the local geographical features. Regional Geography Studies in Honour of Jolán Abonyiné Dr. Palotás. Egyesület Közép-Európa Kutatására, Szeged, I57-I7O. (in Hungarian)

Huber, F. (1996). Long-term local and municipal tasks in tourism development demonstrated with the example of a Great Plain village, Fegyvernek. "Marketing tasks in tourism and environment and health conscious touristic services" Conference. Conference publication. 75-78. (in Hungarian)

Janta, H. (2OII). Polish migrant workers in the UK hospitality industry profiles, work experience and methods for accessing employment. International Journal of Contemporary Hospitality Management, 23 (6-7), 803-8I9.

Janta, H., Ladkin, A., Brown, L., Lugosi, P. (2OII). Employment experiences of Polish migrant workers in the UK hospitality sector. Tourism Management 5, IOO6-IOI9.

Kaspar, C. (1992). Foundations of Tourism. KIT. Budapest. (in Hungarian)

Kaspar, C., Fekete, M. (2OOI). Foundations of Tourism. BGF College of Commerce, Catering and Tourism. Hungarian-Swiss Touristic Further Education Institute. Budapest. (in Hungarian)

Kiss, R. (2OI2). The effects of developing golf tourism on the geographical environment in the region of Belek in Turkey. Földrajzi Közlemények 2, I52-I64. (in Hungarian with English summary)

Ladkin, A. (2OII). Exploring tourism labor. Annual Tourism Research 3, II35-II55.

Lengyel, M. (I992). The general theory of tourism. VIVA Kiadó. Budapest. (in Hungarian) 
Martonné, E. K., Vasvári, M. (2OI2). The results and effects of the touristic development of Hortobágy. Földrajzi Közlemények 3, 293-305. (in Hungarian with English summary)

Máté, A. (2OII). The human side of wine tourism upon the example of the Pannon Wine Region. In: Michalkó, G., Rátz, T. (eds.): Dimensions of tourism: the human factor, economy and politics. Turizmus Akadémia 5. Kodolányi János Főiskola. Székesfehérvár. 82-96 (in Hungarian)

Michalkó, G. (2004). The theoretical foundations of tourism. Turizmus Akadémia. Kodolányi János Főiskola. Székesfehérvár. (in Hungarian)

Michalkó, G. (2007). The theoretical foundations of tourism. Turizmus Akadémia. Kodolányi János Főiskola. Székesfehérvár. (in Hungarian)

Mihály, I., Mihály, P. (2008). Guidelines for Szeged sightseeing. For Szeged guides. Szegedi Egyetemi Kiadó. Juhász Gyula Felsőoktatási Kiadó, Szeged. (in Hungarian)

Mihály, P. (2005). The Szeged-Subotica touristic cooperation with European Union support. Borders and Euroregions. International Geographical Conference. Szeged, 5OI-5O6. (in Hungarian)

Mihály, P. (2006). Culture tourism in the life of Szeged (the 75 year old Szeged Open Air Theatre Festival). "Culture - art - society in the world of globalisation". Conference publication. Szeged. 264-266. (in Hungarian)

Mihály, P. (2007). The Tisza water way: an unduly disregarded touristic potential. "Regions in and over the Carpathian Basin" International Conference. Conference publication. Baja. (in Hungarian)

Mihály, P. (2OI3). The challenges of human resources in Szeged due to the significant increase of Serbian and Romanian visitors and tourists. International Conference. The spirit of the place: The regional development's local dimensions. Conference publication. Győr (in Hungarian)

Nagy, A. (20O2). The touristic infra- and suprastructure of World Heritage locations. Turizmus Bulletin 4, 49-53 (in Hungarian)

Ruszinkó, Á., Vizi, I. (2OIO). The labour market situation of health tourism. Turizmus Bulletin 4, 44-52. (in Hungarian)

Taylor, M., Finley, D., (2009). Three views of "guest workers" in the United States. International Journal of Contemporary Hospitality Management, 2I(2), I9I-2OO.

http://www.icegec-memo.hu/hun/elemzesek/agazati/docs/2006_osz_ingyenes/agazati_ turizmus_2006_okt.pdf. 